\title{
CONSTRUCTION MANAGEMENT AND DESIGN-BUILD/FAST TRACK CONSTRUCTION: A SOLUTION WHICH UNCOVERS A PROBLEM FOR THE SURETY*
}

\author{
C. A. Fostert
}

I

\section{INTRODUCTION}

Despite the almost total absence of literature and case authority regarding suretyship in relation to the construction manager (CM) or in the often troublesome context of design-build/fast track construction, ${ }^{1}$ the tools of logic and analysis coupled with a knowledge of the realities of bonding allow some conclusions to be reached that may have a significant impact on the future bonding of the CM and the nature of performance bonds in design-build/fast track construction projects. Thus, the purpose of this article is to disclose and discuss the inherent difficulties encountered by the surety in bonding both the CM and the designbuild/fast track construction project.

The past decade has witnessed a prodigious growth in the utilization of construction management as an organizational mechanism to improve qualitatively the management of the construction project in order to lower costs and time to completion and, ultimately, to produce a higher quality building. ${ }^{2}$ In the process,

Copyright $(1983$ by Law and Contemporary Problems

* The author gratefully acknowledges the assistance of Scott D. Livingston and R. James Robbins, Jr. in the research and writing of this article.

$\dagger$ Lecturer in Law, Duke University School of Law; Partner, Foster, Conner \& Robson, Greensboro, North Carolina.

1. Extensive research has not revealed any authority discussing in depth the relationship between the surety and the CM or the problems confronted by the surety in a design-build/fast track construction project. Indeed, a fairly exhaustive survey of legal periodicals, reported cases, books, and ForUM, the official publication of the ABA Section of Insurance, Negligence and Compensation Law, disappointingly disclosed no literature specifically addressing the problems presented in this article.

2. In 1982, six of the top twenty design firms received over $40 \%$ of their total revenue billings from construction management. ENG'G NEWS-RECORD, May 13, 1982, at 2. In addition, over ten of the top twenty construction firms obtained over $40 \%$ of their total revenue from construction management. ENG'G News-ReCORD, April 22, 1982, at 22; see also Hart, Construction Management- "CM For Short"-New Name For an Old Game, 8 Forum 211, 216 (1972). Between 1978 and 1979 alone, ENR's top 400 list revealed that the number of construction firms obtaining a significant amount of revenue from CM contracts increased from one-fourth to one-third. Sneed, The Construction Manager's Liability in CONSTR UCTION LITIGATION 317,320 (K. Cushman ed. 1980) (citing ENG'G NEws-ReCORD, April 17, 1980, at 77-78). In the year 1979 the top 50 U.S. general contractors acting as CMs collected construction management fees in excess of $\$ 869,700,000$. Id. Additionally, the top 50 consulting engineering firms acting as $\mathrm{CMs}$ obtained revenues of more than $\$ 432,300,000$. ENG'G NEwS-RECORD, July 31,1980 , at 30 . 
the CM has intruded upon some of the design/inspection functions of the architect and has usurped a substantial part of the traditional managerial function of the general contractor. Notwithstanding this radical realignment of respective functional roles and the glaring absence of authority interpreting the legal consequences thereof, the owner has continued to accept the asserted virtues of the CM, as is evidenced by the increased application of construction management in the face of significant skepticism from the ranks of general contractors and architects. ${ }^{3}$ Likewise, despite the lack of any consensus as to the desirability of designbuild/fast track construction, many owners, having found the surface appeal of such a construction method overwhelming, calmly proceeded to adopt it, without recognizing the intrinsic dangers and problems that design-build/fast track construction necessarily raises for the surety and the owner alike. ${ }^{4}$

From the lonely perspective of the surety, the CM raises at least as many problems as he purportedly solves. Similarly, the deeply rooted bonding problems innate to design-build/fast track construction raise serious questions and concerns about the realistic bondability and consequent viability of such a construction approach. Thus, these two creative concepts in construction present consequential problems of bonding to the surety that the remainder of the construction industry has, apparently, failed adequately to recognize. Accordingly, the surety now comes forward to be heard. This article will, therefore, review the desirability of construction management and design-build/fast track construction from the different perspective of the surety by evaluating them in light of his goals-maximization of profit and minimization of risk.

II

\section{Definition and Function of a Surety}

\section{A. The Specific Purpose of a Surety Bond in a Construction Project}

The essential function of a surety bond is to guarantee the performance of

3. One general contractor has expressed his skepticism by noting that, "[t]hey said the architect was not efficient, but all of a sudden this new guy $[\mathrm{CM}]$ is supposed to be efficient. Well, I don't think he will be any better than the architect. In many cases, I think he will be worse." Hart, supra note 2, at 220 (quoting from Roundtable Discussion, Construction Management and GSA, CONSTruCTOR, Nov. 1971, at 2933). Likewise, one experienced architect has expressed similar skepticism by declaring that, "[i]f the architect properly performs his professional duties and the general contractor adequately fulfills his dual roles of management and coordination, there is no need to indulge in the use of construction management." Interview with R. James Robbins, Sr., Robbins \& Co. Architects, Inc., Tampa, Florida (Jan. 2, 1983). Naturally, the skepticism expressed by architects and general contractors alike should not cause surprise. In fact, inasmuch as the CM arguably encroaches upon some of the traditional functions of the general contractor and the architect, only a warm acceptance as opposed to loud skepticism would be sufficient reason for surprise and bewilderment.

4. "The principal disadvantage of the fast-track approach is that an agreement between the owner and contractor must be reached without the benefit of a complete set of contract documents. Such items as price and time of completion may be more difficult to establish and agree upon under these circumstances." Hapke, Construction Industry Contracts, 23 ST. LouIS U.L.J. 249, 250 (1979). It follows quite logically that both the surety and owner are presented with the difficult problem of bonding an indeterminable amount of risk because the total cost of the project is unknown when it is begun and the performance bond is required. Other equally perplexing problems presented by design-build/fast track construction are discussed below. See infra text accompanying notes $125-43$ 
contractual obligations. ${ }^{5}$ A surety bond is not, however, an insurance policy; rather, it is more accurately characterized as a credit guarantee. ${ }^{6}$ At least one court has distinguished an insurance contract from a surety contract by noting that "[i]nsurance has been defined as a contract whereby one undertakes to indemnify another against loss, damage or liability arising from an unknown or contingent event; whereas a contract of suretyship is one to answer for the debt, default or miscarriage of another ...."7 In addition, as opposed to the insurer, the surety does not anticipate the possibility of loss even in a particular instance or transaction. $^{8}$ As a consequence, the premium paid to a surety is a professional service fee. ${ }^{9}$ The surety, unlike the insurer, has the undiminished right to pursue its principal for indemnification; ${ }^{10}$ in fact, indemnity contracts between the principal and the surety inevitably underlie all performance bonds. "I Insurance merely protects an individual from an unknown risk of loss, while suretyship guarantees the performance of a predetermined, affirmative contractual duty.

The performance bond ordinarily incorporates by reference the terms of the principal's contract. ${ }^{12}$ The integrated obligation of the surety consists, therefore, of the contract, the plans and specifications, and the bond. ${ }^{13}$ Thus, the liability of the surety under a performance bond is completely co-extensive with that of the principal. ${ }^{14}$ As a logical consequence of such congruence in legal obligation, the surety is manifestly entitled to all defenses maintainable by the principal against claims arising from the contract, except for personal defenses such as infancy and

5. J. Sweet, Legal Aspects of Architecture Engineering and the Construction Process $\S 18.01$ (1970); C.A. Foster, Suretyship $\$ 31.2$ (1982) (unpublished manuscript).

6. See J. SwEET, supra note 5, at 363, 365-67.

7. Meyer v. Building \& Realty Serv. Co., 209 Ind. 125, 196 N.E. 250, 253-55 (1935); see also Maryland Casualty Co. v. Hjorth, 187 Wis. 270, 202 N.W. 665 (1925); Maine Lumber Co. v. Maryland Casualty Co., 216 A.D. 35, 214 N.Y.S. 621 (1926); Mahana v. Alexander, 88 Cal. App. 111, 263 P. 260 (1927).

8. Cross, Suretyship Is Not Insurance, 30 Ins. Couns. J. 235 (1963).

9. 1 W. Freedman, RichaRds ON INSURANCE $\$ 35$ (5th ed. 1952); see also J. Sweet, supra note 5, at 363.

10. It is fundamental that a surety, when required to pay its principal's obligation, is entitled to reimbursement. Ellis v. Phillips, 363 Mich. 587, 110 N.W.2d 772 (1961); see also CAL. CIV. CODE $\S 2847$ (West 1983).

11. See C.A. Foster, supra note 5 , at $\S 31$.

12. One court has stated "[i]t is a fundamental rule of construction that where the contract which is the subject of the performance bond is referred to in the latter, that the contract is to be regarded as a part of the undertaking of the surety under the bond." Home Indem. Co. v. F.H. Donovan Painting Co., 325 F.2d 870, 874 (8th Cir. 1963); accord Maine Bonding \& Casualty Co. v. Foundation Contractors, Inc., 105 N.H. 470, 475, 202 A.2d 481, 483 (1964); Paisner v. Renaud, 102 N.H. 27, 149 A.2d 867 (1959); see also Ruckman and Hansen, Inc. v. Contracting \& Material Co., 328 F.2d 744 (7th Cir. 1964); 9 APPLEMAN Insurance LaW and Practice $\$ 5276$ (1941); 4 Corbin Contracts $\$ 800$ (1971); Milana, The Performance Bond and the Underlying Contract: The Bond Obligations Do Not Include All of the Contract Obligations, 12 FORUM, 187, 188 (1976).

13. Milana, supra note 12 , at 188 .

14. The liability of the contractor is the measure of the surety's liability. Smith Eng'g Co. v. Rice, 102 F.2d 492 (9th Cir. 1938), cert. denied, 307 U.S. 637 (1939); Modern Brokerage Corp. v. Massachusetts Bonding \& Ins. Co., 54 F. Supp. 939 (S.D.N.Y. 1944); Dinon Terrazzo \& Tile Co. v. Tom Williams Constr. Co., 148 So. 2d 329 (La. Ct. App. 1963); Maine Bonding \& Casualty Co. v. Foundation Contractors, Inc., 105 N.H. 470, 202 A.2d 481 (1964); East Cross-Roads Center, Inc. v. Melon Stuart Co., 416 Pa. 229,205 A.2d 865 (1965); Riley Constr. Co. v. Schillmoeller \& Krofl Co., 70 Wis. 2d 900, 236 N.W.2d 195 (1975).

The liability of the subcontractor is the measure of his surety's liability. Rocky Mountain Tool \& Mach. Co. v. Tecon Corp., 371 F.2d 589 (10th Cir. 1966); Thomas Haverty Co. v. Pacific Indem. Co., 215 Cal. 555, 11 P.2d 864 (1932); Sorenson v. Robert N. Ewing, 8 Ariz. App. 540, 448 P.2d 110 (1968). 
insanity. ${ }^{15}$ When the principal is precluded from asserting a defense, the surety is likewise barred from affirmatively relying on it. ${ }^{16}$

Upon default by the principal contractor, the burden of contract performance is transferred in toto to the surety. ${ }^{17}$ In this event, the surety may exercise numerous options in order to discharge his liability for performance: (1) finance the existing contractor until completion, (2) perform as a general contractor and complete the contract himself, (3) relet the contract to a new contractor and pay any excess cost of completion, or (4) allow the owner himself to find a new contractor and pay any excess cost incurred to complete. ${ }^{18}$

\section{B. The Purpose of the Surety in the Industry}

At the macroeconomic level, the surety bond is nothing more than a mechanism for spreading the risk and associated cost throughout the industry. ${ }^{19}$ This result obtains because the performance bond shifts some of the liability for error, both negligent and nonnegligent, from the owner to the surety. With a bond, the owner is guaranteed error-free performance of his contract, and he need look no further than the surety for it. Moreover, the owner usually requires a performance bond as a condition precedent to the bid or negotiation of a construction contract. ${ }^{20}$ Consequently, the contractor will necessarily include the expected bond fee in his bid for the contract, either as an included cost or, more often, as a specific line item added to his base price for construction. It follows quite logically that the cost of the bond is transferred to the owner, ${ }^{21}$ who in turn passes the cost on to his building tenants, either himself or others, as the producers of goods or services. On an industry-wide scale, the surety bond goes far to accomplish the desirable goal of equitably spreading the risk of both nonnegligent and negligent error. As a result, the protection and guarantee afforded by bonding allows the owner to sleep peacefully without the distressing fear of unanticipated extra costs or prolonged litigation.

Although the owner is not motivated by altruism, his demand for a surety bond and the consequent spreading of risk and cost of error accomplished thereby, rather than "point loading" it, provide a general economic benefit for the entire construction industry. When a single entity must bear all or a disproportionately large amount of risk, an inefficient allocation of resources results for two primary

15. Riley Constr. Co. v. Schillmoeller \& Kroff Co., 70 Wis. 2d 900, 905, 236 N.W.2d 195, 198 (1975).

16. Cohen v. Mayflower Corp., 1962 Va. 1153, 1161, 86 S.E.2d 860, 866 (1955).

17. See Sorenson v. Robert N. Ewing, 8 Ariz. App. 540, 541, 448 P.2d 110, 111 (1968).

18. C.A. Foster, supra note $5, \S 31.7$.

19. See Comment, Mississippi Law Governing Private Construction Contracts: Some Problems and Proposals, 47 Miss. L.J. 437, 458 (1976). To the extent that the judgment of the surety is mistaken regarding the contractor's ability to perform and his net worth (bonding capacity), in case of default, the surety accepts some risk insofar as he may be unable to recover from the principal the total amount of his liability to the owner for completion of the contract. Even more important, the premium for the bond, which is ultimately adjusted for loss experience, allows the cost for such risks eventually to be shifted from the contractor to the owner in the form of a higher contract price, and then finally, to the tenant in the form of a higher rental fee.

20. C.A. Foster, supra note 5.

21. Id. 
reasons. First, the "free-rider" problem surfaces because one individual may rely on the risk bearing individual, who is forced to accept all the risks for a particular activity. In the construction context, the subcontractor might rely on the contractor when the liability for the entire project was point loaded at the contractor level, rather than spread throughout the industry by bonding. Second, risk means uncertainty, so that the greater the risk, the greater the uncertainty involved. It is clear that the spreading of risk through bonding gives each entity a smaller amount of risk (uncertainty); and thus decisions made by each entity should be more accurate regarding the future than would otherwise be the case, such as where one party is forced to accept all the risk entailed by a particular project. Quite incidentally, therefore, the owner's bond requirement provides a general economic benefit to the construction industry as a whole.

Finally, in determining whether to bond the owner's selection of the contractor, the surety acts as a pre-screen. ${ }^{22}$ The surety will not authorize bonding until a threshold determination has been made that a particular contractor has sufficient bonding capacity for the project in question together with all other projects on which the contractor is simultaneously engaged. The implicit sine qua non to the excution of a bond is, therefore, a judgment that the contractor's bonding capacity and his character are sufficient to assure recovery in case of default; that judgment should be made after examining the net worth of the contractor, the contractor's historical success, and the scope of the project involved. ${ }^{23}$ The pre-screening conducted by the surety is an indispensable and salutary function of bonding in construction. As a caveat, however, it should be noted that practical considerations frequently intrude into this theoretical evaluation, and the surety either does not examine the bonding capacity of the contractor or does so very inadequately. Indeed, at least one commentator has remarked lamentably that

[t] he surety must, or should, be aware of the terms and provisions of the contract. I am sure, however, that we who handle contract surety losses know full well that not too many underwriters have ever seen the underlying contract or even know generally what it provides other than the fact that it covers the construction of some structure. ${ }^{24}$

To be sure, the surety provides an indispensable function: spreading the risk. It is axiomatic that without the performance guaranteed by the surety, only owners with virtually an immeasurable net worth and a rare gambling instinct would be inclined to accept the costly uncertainty intrinsic to construction. As a necessary

22. C.A. Foster, supra note $5, \S 31.2$; J. SWEET, supra note 5 , at 366

23. Milana, supra note 12 , at 188 . With respect to the surety's duty of inquiry and investigation, the courts have uniformly held

The obligee is not under an obligation to disclose to a surety information of which the surety has knowledge readily to [sic] hand. A surety cannot 'rest supinely, close his eyes, and fail to seek important information' and then seek to avoid liability under the guaranty by claiming he was not supplied with such information.

Marine Midland Bank v. Smith, 482 F. Supp. 1279, 1287 (S.D.N.Y. 1979) (quoting Mohasco Indus. Inc. v. Groffen Indus. Inc., 335 F. Supp. 493, 497 (S.D.N.Y. 1971)). The Supreme Court held as early as 1875 that "[i]f the surety desires information, he must ask for it. The creditor is not bound to volunteer it. An undisclosed prior debt will not affect the validity of the contract." Magee v. Manhattan Life Ins. Co., 92 U.S. 93, 99 (1875). Manifestly, the duty to obtain bonding information has been placed squarely on the surety.

24. Milana, supra note 12 , at 188. 
consequence, the viewpoint of the surety regarding the CM and design-build/fast track construction is of great concern to those who are either intentionally or reluctantly woven into the immense and complex patchwork of the construction industry.

With the purpose of the surety now in mind, it is necessary to review traditional construction contract alignments and the position of the surety therein, to demonstrate the differences and problems inherent with the introduction of the agency CM and design-build/fast track construction.

III

\section{Traditional Construction Contract Alignments}

\section{A. Owner-Architect}

The first element of the traditional construction contract alignment is a contract between the owner and the architect. This contract is frequently based on standard forms prepared by the American Institute of Architects (AIA) ${ }^{25}$ and "typically makes the architect the agent of the owner and defines the specific responsibilities of the architect during the design and construction of a given project."26

Under this contract, the architect obligates himself to develop a schematic design based on the owner's needs and budget. ${ }^{27}$ In accordance with this schematic design, the architect prepares design documents for the entire project. ${ }^{28} \mathrm{He}$ next proceeds to develop construction documents setting out project specifications as well as bidding and regulatory information. ${ }^{29}$ Based upon the construction documents, the architect assists the owner in obtaining bids and awarding the contracts for construction. ${ }^{30}$ Thereafter, the architect begins perhaps the largest part of his job by assuming responsibility for the administration of the construction contract entered into by the owner, ${ }^{31}$ including: the responsiblity to visit the project at intervals "to become generally familiar with the progress and quality of the work," 32 the task of certifying payments to the contractor, ${ }^{33}$ the role of interpreting the contract documents, ${ }^{34}$ the authority to reject nonconforming work, ${ }^{35}$ and the

25. Telephone interview with Dale R. Ellickson, Director of Documents, American Institute of Architects, Washington, D.C. (Jan. 5, 1983). Mr. Ellickson stated that AIA documents are "extensively used" in the private sector of the construction industry.

26. Note, The Roles of Architect and Contractor in Construction Management, 6 U. MICH. J.L. REF., 447, 449 (1973). See generally American Institute of Architects, Standard Form Agreement Between Owner and Architect, Doc. B141 (July 1977) [hereinafter cited as AIA Owner-Architect Agreement], reprinted in H.M. Hohns, Desk BoOk of Construction Contract LAW - With Forms 184 (1981).

27. AIA Owner-Architect Agreement, supra note 26, art. 1.1.

28. Id. art. 1.2.2.

29. Id. art. 1.3.

30. Id. art 1.4.1.

31. Id. art 1.5.2.

32. Id. art. 1.5.4.

33. Id arts. 1.5.7, 1.5.8.

34. Id. arts. 1.5.1, 1.5.9.

35. Id. art 1.5.12. 
task of determining final and substantial completion. ${ }^{36}$

Despite the architect's wide variety of functions, his two overriding roles in the traditional contract model are that of design professional, a role in which the architect provides the owner with the product-design documents, and of agent for the owner in the construction phase of the project. In the latter role, the architect is primarily providing the owner with a service, employing his expertise and knowledge to evaluate the progress and quality of construction on the project. The architect is generally compensated for both functions on a fee basis. ${ }^{37}$

\section{B. Owner-Contractor}

The next addition to the traditional alignment is the general contractor who, having been normally selected on the basis of his low bid or negotiated price on the project, contracts directly with the owner. ${ }^{38}$ In the typical form of contract between owner and general contractor, the latter agrees to construct the project for a stipulated sum. ${ }^{39}$ In this contractual arrangement, the entrepreneurial risk and benefits are placed upon the general contractor. He has given his price; if he completes the project for more or less, he absorbs the corresponding loss or profit. With respect to payment of the stipulated sum, the owner typically agrees to various progress payments when different stages of the work are completed, ${ }^{40}$ as well as a final payment when the project is complete. ${ }^{41}$

In this traditional contract alignment, the general contractor is saddled with both management and production responsibilities. These dual obligations are best illustrated in AIA Document A201, General Conditions of the Contract for Construction (General Conditions), which states: "[T]he Contractor shall supervise and direct the Work ... . He shall be solely responsible for all construction means, methods, techniques, sequences and procedures and for coordinating all portions of the Work under the Contract." 42 The General Conditions further reinforce the general contractor's management duties by placing upon him the obligation to keep "a competent superintendent . . . in attendance at the Project site"43 and to prepare a proper schedule providing for "expeditious and practicable execution of the Work." 44

While general contractors often perform at least a portion of the actual construction work with their own labor and supplies, the vast majority of the work done on a project site is undertaken by various subcontractors who contract

36. Id. art. 1.5 .15 .

37. See J. SWEET, supra note 5, at 104.

38. American Institute of Architects, Standard Form Agreement Between Owner and Contractor (stipulated sum), Doc. A101 (June 1977) [hereinafter cited as AIA Owner-Contractor Agreement], reprinted in $\mathrm{K}$. Cohler, Construction Contracts 307 (1979).

39. Id.

40. Id. art. 5 .

41. Id. art. 6 .

42. American Institute of Architects, General Conditions of the Contract for Construction, Doc. A201, art. 4.3.1 [hereinafter cited as AIA General Conditions], reprinted in K. COHLER, supra note 38, at 311.

43. Id. art 4.9 .1 .

44. Id. art 4.10 .1 . 
directly with the general contractor. ${ }^{45}$ It is in directing the subcontractors, especially in scheduling and coordinating their work, that the general contractor encounters his heaviest managerial burden.

\section{The Surety and the Traditional Contract Alignment}

To obtain further assurance that a general contractor's obligations on a project will be properly performed, owners turn to the surety's bond as an effective means of risk shifting. On the benefits of bonding, one commentator has stated:

Both in theory and in practice, the use of bonding in . . . construction contracts is highly advantageous. The bond affords maximum protection to the owner for contract comple-

tion .... In addition, it causes little difficulty to the conscientious prime contractor who completes his contract since the additional costs involved are passed on to the owner. ${ }^{46}$

In the traditional contract alignment, sureties typically write four kinds of bonds: first, a performance bond guaranteeing the performance of the general contractor's contract with the owner; ${ }^{47}$ second, a payment bond guaranteeing the general contractor's obligation to pay his workmen, subcontractors, and suppliers for labor and materials used in the performance of his contract with the owner; ${ }^{48}$ third, a series of performance bonds guaranteeing the subcontractors' performance and their contracts with the general contractor; and finally, payment bonds guaranteeing that various subcontractors will pay for all materials and labor used in the performance of their contracts with the general contractor. ${ }^{49}$ Irrespective of the type of bond, the surety's bond is a guarantee of the underlying contract. The penal amount of the bond is based on the contract price.

Focusing on the performance bond guaranteeing the general contractor's contract with the owner, the surety is bonding both the general contractor's management and production duties under the contract. The bond is for performance of the contract, ${ }^{50}$ and the general contractor's performance includes both of these responsibilities. ${ }^{51}$

As previously mentioned, 52 upon a default by the general contractor, the surety may (1) step in and complete the contract; or (2) allow the owner to contract with another contractor and make available to the owner "sufficient funds to pay the cost of completion less the balance of the contract price, but not exceeding" the

45. Id. art. 5.1.1; see also Executive House Building Inc. v. Demarest, 248 So. 2d 405, 411 (La. Ct. App. 1971).

46. Comment, supra note 19 , at 458 .

47. American Institute of Architects, Performance Bond, Doc. A311 (Feb. 1970) [hereinafter cited as AIA Performance Bond], reprinied in H. Hauf, Building Contracts for Design and Construction 191 (1976)

48. American Institute of Architects, Labor and Material Bond, Doc. A311 (Feb. 1970) [hereinafter cited as AIA Labor and Material Bond], reprinted in H. HAUF, supra note 47, at 193.

49. It is significant to note that the architect's contract with the owner is unbonded, reflecting the fact that the architect assumes no responsibility for the production or management of the actual construction work. His professional function extends only to the production of design documents and the evaluation of the work. The owner is at least partially protected in these two areas by the architect's professional liability insurance, which covers negligent acts or omissions of the architect.

50. AIA Performance Bond, supra note 47.

51. AIA General Conditions, supra note 42, art. 4.3.1.

52. See supra note 18 and accompanying text. 
penal amount of the bond. ${ }^{53}$ Under the first option, once the surety decides to complete, he becomes liable for the entire cost of completion less only the unpaid contract price. Thus, under this option, it is possible for the net cost to the surety for performance to exceed the penal amount of the bond. ${ }^{54}$ For this reason, sureties are often reluctant to assume responsibility for completion. ${ }^{55}$

Even with a bonded contract, an owner is not entirely protected from a general contractor's default; if the damages caused by the default exceed the penal amount of the bond, these additional costs fall upon the owner. On balance, however, a surety does provide an owner with substantial protection ${ }^{56}$ at a relatively insignificant cost. ${ }^{57}$ The general contractor's performance bond guarantees the overall management and production of the project. It also allows the owner a single and indentifiable place to seek recovery for a default in the performance of his contract with the general contractor. Through a surety bond, an owner is assured that his contract with the general contractor will be performed. Thus, the owner obtains an additional guarantee that his project will be delivered in accord with the design documents, on time, and within the contract price. Obviously, the surety benefits from writing bonds because of the fee obtained for each bond that is written-the larger the contract, the larger the bond, the larger the fee. ${ }^{58}$ In theory, the surety should face little or no risk under a bond. On this notion, one author recently stated:

The concept of suretyship in the underwriting of surety bonds for the construction industry theoretically presupposes the surety will suffer no loss. The surety underwriting is merely viewed as extending a form of credit for a fee under which the principal and indemnitors have joint and several qualifications of integrity and financial responsibility to perform all their obligations. ${ }^{59}$

From a practical standpoint, however, the surety does accept some risk in

53. AIA Performance Bond, supra note 47. "Balance of the contract price" is defined as the total amount of the contract between owner and general contractor less that already paid to the general contractor. Id. Thus, the surety is only liable for any amount by which the default causes the total outlay by the owner to exceed the original contract price. As a practical matter, if the penal sum of the bond is equal to the contract price, the surety is never liable for more than the "balance of the contract price."

It also should be remembered the surety always has the third option of financing the existing contractor until completion. See supra text accompanying note 18. The exercise of such an option by a surety is an effort to cure a default by the contractor. Such financing, however, is a high risk option because "sums advanced . . . do not result in credit against the penal sum of the bond." Cochrane, Obligations of the Principal's Subcontractors and Suppliers at Default and Takeover by the Surety, 14 FOR UM 869, 870 (1979).

54. Cochrane, supra note 53 , at 871 .

55. C.A. Foster, supra note $5, \S 31.7$

56. The two primary areas of owner risk are (1) overcertification by the architect or design professional (in which case he has an action against the architect or design professional), see J. SwEET, supra note $5, \S 24.08$, and (2) claims for delay by other prime or subcontractors resulting from failure of the general contractor in his management functions.

57. Rodimer, Use of Bonds in Privale Construction, 7 Forum, 235, 238 (1972).

58. It should be noted, however, that the effective fee rate charged for bonding, which is based on percentages of the contract price, decreases as the contract price increases. A typical fee schedule used by the surety industry for building contracts spanning less than 24 months includes the following rates: $\$ 12$ per $\$ 1,000$ for the first $\$ 500,000$ of contract price; $\$ 7.25$ per $\$ 1,000$ of an additional $\$ 2,000,000$ of contract price; $\$ 5.75$ per $\$ 1,000$ of an additional $\$ 2,500,000$ of contract price; $\$ 5.25$ per $\$ 1,000$ of an additional $\$ 2,500,000$ of contract price; and $\$ 4.80$ per $\$ 1,000$ of contract price over $\$ 7,500,000$. Telephone interview with Richard C. Charles, Aetna Lifè and Casualty Co., Charlotte, N.C. (Jan. 5, 1983) 1 .

59. Meeker, Surety's Right to Specific Performance of Indemnity Agreements, 3 ConST. LAW., Spring 1982, at 
bonding construction contracts. This risk is, however, clearly minimized by the surety's review of the financial condition, experience, and character of those he bonds; the surety's right to indemnity from the principal or his indemnitor; 60 and the surety's ability to maintain almost any defense from liability or claim against others that could be asserted by the principal. ${ }^{61}$ Bonding contracts in the traditional contract alignment is an advantageous risk avoidance mechanism for the owner and the source of substantial profit for the surety.

\section{IV}

\section{The Agency CM Contract Alignment}

\section{A. Changes in the Traditional Contract Alignment}

When a CM is injected into the owner-contractor-design professional regime, the question arises whether from the standpoint of the surety and the goals of suretyship the modification is an equally beneficial construction alignment as compared to the traditional arrangement. Logic teaches even the reluctant construction pupil that in terms of these objectives it is not as beneficial an arrangement as one might initially conclude.

The first step in reaching this conclusion is an understanding of the contract position and function of a CM. There is no set contract alignment for construction management projects. A CM can contract to perform a variety of services in a variety of ways for an owner. ${ }^{62}$ This article, however, focuses on the CM in his purest form, that of an agent managing a project for the owner from design to delivery for a set fee. ${ }^{63}$

The introduction of a CM as an agent of the owner with reference to the project greatly alters the traditional contract alignment. The first alteration occurs in the relationship between the owner and the architect. While the owner still contracts with the architect (assuming the CM does not provide design services), at least a portion of the duties once solely in the province of the architect are now shared with the CM. Most of these shared responsibilities occur during the construction phase of the project, ${ }^{64}$ including inspections of the work to ensure conformance with the contract documents, ${ }^{65}$ the duty to reject nonconforming work, ${ }^{66}$ and an obligation to report the percentage of work completed for the purpose of

60. Pearlman v. Reliance Ins. Co., 371 U.S. 132, 136-37 (1962); Cross, supra note 8.

61. Cochrane, supra note 53.

62. See generally Hart, supra note 2 , at $211 \cdot 13$.

63. For a schematic comparison between the traditional and the agency CM alignments, see Barry \& Paulsen, Professional Construction Management, AM. SoC. Civ. ENG. J. Constr. Div., 425, 429 (Fig. A and E) (1976). Cf. Dekalb County v. PMS Constr. Co., 148 Ga. App. 413, 251 S.E. 2d 334 (1978).

64. The CM does, however, assume some responsibility over design, an area solely the function of the architect in the traditional contract alignment. The most significant of these design responsibilities is a review of design drawings and specifications in preparation of a project budget. American Institute of Architects, Standard Form Agreement Between Owner and Construction Manager, Doc. B801 (1980), arts. 1.1.1, 1.1.3., 1.1.4 (1980) [hereinafter cited as AIA CM Agreement], reprinted in H.M. HoHNS, supra note 26, at 185 .

65. Id. art. 1,1.12.

66. Id. 
certifying payments. ${ }^{67}$

Perhaps the most striking change in the traditional alignment brought about by the introduction of the agency CM is the removal of the general contractor as the manager of the work. Under an agency $\mathrm{CM}$ regime, the owner contracts directly with multiple prime contractors. These prime contractors are essentially the subcontractors who contracted with the general contractor in the traditional format. They serve the same functions as subcontractors-performing the actual construction work-but now, as a result of direct contract with the owner, they have new names and new characteristics. ${ }^{68}$

The deletion of the general contractor by the CM arrangement brings about more changes from the traditional contract alignment than just a new name for subcontractors. Most significant among these changes is a shifting of "the management function previously performed by [the] general contractors." 69 The CM assumes the duty to "[c]oordinate the Work of the Contractors . . . to complete the project in accordance with the Owner's objectives on cost, time, and quality." "70 The CM obligates himself to "provide a detailed schedule for the operations of the contractor," 71 and to monitor this schedule as production progresses. ${ }^{72}$ Finally, the CM takes on the duty to "[i]nspect the work of the Contractors to assure that the Work is being performed in accordance with the requirements of the contract documents." 73 While this language defining the CM's management duties is not as direct and specific as that defining the management role of the general contractor, ${ }^{74}$ it is readily apparent that the $\mathrm{CM}$ is contracting to perform the same functions as the general contractor in the traditional alignment-to manage those who are performing the construction. But, unlike the general contractor, the CM in the private sector typically carries no performance bond on his contract with the owner. ${ }^{75}$

B. The Effects of the Agency CM Alignment on the Surety and the Goals of Bonding

The most immediate and obvious effect upon the surety brought about by the introduction of the agency $\mathrm{CM}$ is a reduction in the bonding fees which the surety collects. The surety no longer has the opportunity to write a performance bond based upon the general contractor's entire contract with the owner. This effect is

67. Id. art. 1.1 .15 .

68. These new characteristics stem from the prime contractor's direct contract with the owner and include the right to have a mechanics', laborers', or materialmen's lien against the project, see, e.g., N.C. GEN. STAT. § 44A-8 (1981); Gateway Erectors Div, of Imoco-Gateway Corp. v. Lutheran Gen. Hosp., 102 Ill. App. 3d 300, 301, 430 N.E.2d 20, 21 (198I), and the right to go against the owner or his agent for improper scheduling. See Foster, Presenting/Defending the Claim for Delay, Disruption, or Interference, in WINNING AND NOT LOSING at IV-28 (1983).

69. K. COHLER, supra note 38 , at 43.

70. AIA CM Agreement, supra note 64, art. 1.1.18.

71. Id. art 1.1.8.2.

72. Id. art 1.1.8.3.

73. Id. art. 1.1.12.

74. In the traditional agreement between owner and general contractor, the contractor agrees to "supervise and direct the work." See supra note 42 and accompanying text.

75. Telephone interview with Richard C. Charles, supra note 58. 
especially significant because the general contractor's performance bond is the largest bond written by the surety in the traditional arrangement. While the surety may still write performance bonds on each of the prime contractors' contracts with the owner, the aggregate amount of these bonds is no more than that of the subcontractors' performance bonds on their contracts with the general contractor in the traditional arrangement. Thus, from the perspective of the overall project, sureties have less to bond and, correspondingly, absent an adjusted rate schedule, smaller fees to collect.

Smaller fees for the surety, however, are not the only significant developments brought on by the functional disappearance of the general contractor and his performance bond. Viewing the CM alignment from an industry-wide perspective, it is clear that the protection given the owner through suretyship has been substantially reduced by the introduction of the CM. While one commentator has stated that a benefit of having multiprime contractors, as opposed to a traditional general contractor, has been to do away with unneeded "double layers" of bonding, ${ }^{76}$ properly analyzed, this change is not actually a benefit.

The two levels of bonding are different, and both are needed to give the owner proper protection. Admittedly, performance bonds on both the subcontractors and the general contractor necessarily result in an overlap in bonding the production aspects of a project. Nevertheless, this double level of bonding serves a very important and often overlooked purpose. At the first level, the subcontractors' bonds on their contracts with the general contractor guarantee only segmented areas of production. Such segmented bonding is necessary to ensure the performance of the subcontractors and to give the general contractor an easily identifiable party from whom to seek indemnity in the case of default. The second level of bonding-the bond between the general contractor and the owner-offers an entirely different shield of protection to the owner. First, the bond guarantees the management function of the general contractor. Second, it guarantees the production of the project as a whole. Finally, the general contractor's performance bond places the separate areas of production and management under one bond. Thus, in the case of a default the general contractor's single, aggregate performance bond also gives the owner one target for the satisfaction of his construction contract, rather than having to face the obvious problems of dealing with a large number of separately bonded prime contractors. ${ }^{77}$

Accordingly, while each level of bonding in the traditional contract alignment serves a unique and needed function, the introduction of the agency CM dangerously removes the second level of bonding. Because the CM is not bonded, ${ }^{78}$ the owner no longer has a bond guaranteeing the management of the project. Put another way, the management of a project has been shifted to the CM, but the bond assuring the performance of this management function has not followed. Nor does the owner have a single bond which guarantees production as a whole. Finally, overall production and overall management are never guaranteed

76. Hapke, supra note 4 , at $250 \&$ n.2.

77. Hart, supra note 2 , at 223.

78. Telephone Interview with Richard C. Charles, supra note 58. 
together. As a consequence, upon a default the owner faces the risk that each party will point the finger at someone else because no one bonded entity has the ultimate responsibility for guaranteeing overall performance.

Thus, with the introduction of the CM, the bond guarantees accruing to the owner on a given project are drastically reduced. The size of the project has not changed, nor has the actual work required to complete the project diminished. In carving the traditional contract alignment into different pieces, the CM has, however, left the owner with larger risk exposure than he faced under the traditional contract scheme. The sum total of the project cost is precisely the same, yet the sum total of bond protection has been reduced by nearly one-half. ${ }^{79}$ More important, this enormous reduction in the owner's bonding protection has gone largely unnoticed by the industry since the welcomed arrival of the CM.

\section{V \\ Inherent Problems Involved in Bonding the Agency CM}

The question that immediately comes to mind is why not resolve at least part of this problem by bonding the CM? To a very small extent, such a measure would fill the bonding void created by the agency CM; however, bonding the CM to the point where the entire void is filled is an impractical and economically inefficient solution to the problem of a diminished guarantee or augmentation in risk to the owner.

\section{A. The Inadequacy of Protection Given by Bonding the CM Under Current Standard Contract Documents}

Presently, bonding the CM under the typical CM contract does not accomplish the underlying purpose of bonding, namely, the shifting of risk. This conclusion, contrary to the intuitive reaction, is logically required because the risk of negligent error is not substantially affected by the surety bond insofar as professional errors and omissions insurance already adequately covers negligent error, ${ }^{80}$ and the risk of nonnegligent or contractual error by the CM cannot be completely reached by a normal performance bond.

79. See app. A.

80. To the extent that negligent error affects contractual performance, the coverage of the typical performance bond will include the risk of such negligent error. When, however, the specific negligent act or error of the principal-contractor does not affect contractual performance, the scope of the performance bond will not include and protect against this type of negligence. Thus, the performance bond does not cover personal injuries and other similar torts. Franklin, Problems of the Performance Bond Surety With Casualty Insurance Exposures, 16 FORUM, 567, 568-69 (1980). This result obtains because

[i]f a tort claimant were to be able to look to the surety bond for funding his remedy, the class of persons whom the bond was intended to protect would not be protected. The bond would be depleted by tort claims.

If tort claimants were allowed to recover on a contract surety bond, or if the owner or obligee were entitled to recover from his surety company any judgment rendered against him or in favor of a third party tort claimant, it is quite conceivable that there would be no money left out of the surety bond for the payment of claims . . . . [T/o hold that a tort claimant has a cause of action on a performance bond or that the surety is a tort insurer would be to exclude that class of persons a surety bond is intended to protect.

Id. at 568-69. 
The risk of negligent error by the CM has historically been and is presently covered by professional errors and omissions liability insurance. The coverage of a typical liability insurance policy for a CM includes "liability arising out of any negligent act, error, mistake or omission in rendering or failing to render professional services of the type described . . . [excluding] liability . . . assumed by the Insured by agreement under any contract, whether oral or in writing, unless such liability would have attached to the Insured even in the absence of such agreement ...."81 At least in theory, the risk of negligent error committed by the CM is spread efficiently throughout the industry primarily by professional liability insurance. ${ }^{82}$

The more serious and indeed the more perplexing problem with spreading the risk of error caused by the CM lies in the remedy available to the owner upon contractual breach or error. The CM is a professional and therefore the nature of the agreement between the CM and the owner is that of a service contact. ${ }^{83}$ The CM becomes the agent for the owner and he is paid a professional fee as consideration for his managerial services. ${ }^{84}$ Not surprisingly, the professional fee negotiated by the CM is only a small percentage of the total contract price. ${ }^{85}$ It follows that a surety bond guaranteeing performance by the CM of his managerial function up to the amount of the contract or professional fee will be wholly inadequate both to protect the owner and to achieve the goal of spreading the risk of managerial error. Further, the owner as a result of his agency relationship with the CM is initially liable for the negligence of the CM within the scope of his agency relationship. ${ }^{86}$

81. Imperial Casualty and Indemnity Co., Architects, Engineers and Construction Managers Professional Liability Insurance Policy No. AE, Form No. 4-02 574 [hereinafter cited as Insurance Policy].

82. It should be cautioned, however, that in the practical world of construction management, it is often extremely difficult to prove negligence. Each construction project is unquestionably unique, making it difficult to develop a priori pre-construction standards of care of which the CM can take cognizance and to which he can conform his conduct. Furthermore, experience sadly reveals that

the concept of insurance is a very large cause of construction litigation. The idea of a source of real money (someone else's) being available to pay for error, omission or act of negligence is a lawyer's dream. When everyone on a jury thinks that insurors make money on top of money, the idea of going to court to recover losses increases in appeal.

H.M. HoHns, supra note 26 , at 31 . Of even greater concern and practical importance, the deductibles for professional liability insurance have increased so astronomically in recent years that architects and CMs are essentially self-insured. Thus, professional liability insurance does not cover all the damages directly and proximately caused by the negligence of the design professional or CM. Due to the large deductible, therefore, the risk of negligent error is spread neither completely nor optimally. Id. As a consequence, "[s]ome have contended that the trend toward imposing liability without fault for defective products should be expanded to those who perform design services. Adoption of such a standard would relieve the plaintiff from the burden of showing that the design professional was negligent." J. SwEET, supra note 5, at 755. Nevertheless, the courts have not yet extended the strict liability principle to those who perform services, such as architects, engineers, and CMs. Id.

83. Sneed, supra note 2 , at $329 \&$ n.62.

84. Id. at 307-08. For the principle that the CM is the agent of the owner, see supra notes $63-75$ and accompanying text.

85. The CM's fee is generally only about $2 \%$ to $3 \%$ of the total direct project cost. Telephone interview with Richard D. Conner, General Counsel to Construction Management Association of America, Inc., and various specialty trade associations (Jan. 10, 1983). But see BusInessman's GUIDE TO CONSTRUCTION 164 (1980) (the typical CM fee is stated to range from $3 \%$ to $6 \%$ of the total contract price) My experience in dealing professionally with CM's has been that the former estimate more closely approximates the "average" CM fee.

86. "A principal is bound by all that a general agent does within the scope of the business in which he 
In addition, although the fee represents only a small amount of the entire project cost, and the coverage of the bond is limited to that amount, the ultimate liability arising from nonnegligent error by the CM may easily have a cost impact far in excess of the bond limitation. ${ }^{87}$ Thus, the surety can bond an agency CM; however, the protection given the owner by doing so is effectively de minimis ${ }^{88}$ and the bonding of such a service contract fails to effect a distribution of the risk of nonnegligent error throughout the industry.

Writing a performance bond based on the CM's contract with the owner has the added shortcoming, almost paradoxically, that it bonds too much. A bond on a CM contract would provide guarantees on services that have not required bonding in the past, such as those services formerly provided by the architect and now undertaken by the CM. ${ }^{89}$ Assuming again that the CM carries errors and omissions insurance similar to that carried by design professionals, there is no need to bond these services. Bonding the CM is therefore not the best solution because it overinclusively guarantees some services that are protected elsewhere.

\section{B. Possible Solutions to the Problems of Bonding the Agency CM}

One solution to the problem of bonding a $\mathrm{CM}$ service contract that readily suggests itself is to alter the terms of the underlying contract to increase the liability and thus raise the bond limitation on the new contract. On the surface, at least, such a proposal is attractive, but upon a more searching analysis, the solution is clearly inadequate, if not untenable.

First, the CM contract could be altered painlessly so that the CM would be responsible for production (actual construction) and management.90 This enhancement of the CM's responsibility would give rise to a more traditional con-

is employed as such general agent . . . " Butler v. Mapels, 76 U.S. (9 Wall.) 766, 770 (1870); cf.

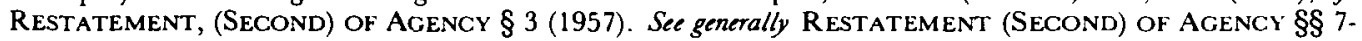
8 (1957). The classic statement on this subject by Evans, however, is that, "[a] principal is liable to third parties for whatever the agent does or says; whatever contracts . . . he makes; . . . whatever negligence he is guilty of . . provided the agent acts within the scope of his apparent authority, and provided a liability would attach to the principal if he was in the place of the agent . . . "W. EVANS, A TREATISE UPON THE LaW of Principal and Agent In Contract and TORT, 440 (Am. ed. 1879). More specifically, in the more novel context of construction management, the courts have consistently held that "an agent [CM] for a disclosed principal is not liable for the nonperformance of the contract," unless he takes an active part in violating the contract or duty the principal owes to a third person. See e.g., Gateway Erectors Div. of Imoco-Gateway Corp. v. Lutheran Gen. Hosp., 102 Ill. App. 3d 300, 302, 430 N.E.2d 20, 22 (1981). The $\mathrm{CM}$ is, however, liable in tort to third parties. Id.

87. Due to the interdependence of each party to a construction project, a managerial or coordinating error by the CM may have an extraordinarily disproportionate impact on the costs incurred by all other parties. To take only one hypothetical situation, a managerial decision causing the project to be delayed could easily cause an unforeseen substantial cost escalation in an inflationary economy. Moreover, even in a noninflationary economy, the cost of delay, especially field overhead and extended home office overhead, can be enormous. Surprisingly enough, extended home office overhead can approach $1 \%$ of the total contract sum per month of delay. Foster, supra note 68 , at IV.77.

88. The protection is not only de minimis, but it is also uncertain as to what it covers. This fact was strikingly revealed by Marvin L. Powell, Executive Vice President of Heery Program Management, Inc., who, in describing a bond written on an agency CM contract stated: "No one, including . . . the bonding company. . . knows what has been bonded." Letter from Marvin L. Powell to C. A. Foster (Nov. 8, 1982).

89. See supra notes 64-67 and accompanying text.

90. Under this type of CM contract, the CM would actually perform at least some of the construction work. See generally Conner, Contracting for Constnuction Management Services, LAW \& CONTEMP. Probs., Winter 
struction contract and thus permit bonding the entire cost of the project. With this expansion of the CM's responsibility and associated contractual liability, the owner would be fully protected and the risk of nonnegligent error would be spread throughout the industry. However, this "solution" merely turns the CM into a hybrid form of a general contractor, eliminating the need for a CM as an agent of the owner. This would deny the owner the typical benefits of utilizing a CM at the project, namely the benefit of having an agent whose interests are identical to those of the owner. When the risk of profit or loss is introduced into the CMowner relationship, it inevitably creates a deleterious conflict of interest. Once the CM becomes the pecuinary adversary of the owner, the CM's actions will be controlled strictly by his own profit motive irrespective of the effect his actions have on the owner. Merely molding a general contractor out of a reluctant CM destroys the essential function of the CM, and is obviously no solution to the bonding dilemma.

Second, the CM contract could be rewritten so that the CM has final responsibility for completion of performance in accordance with the contract specifications yet no responsibility for actually performing a significant amount of the construction work. More specifically, the CM under such a contract would be liable for completion up to the entire cost of the project. Thus, the CM would be liable for the entire contract even though he has no actual performance duty actually to perform and no accompanying ability to exercise control over the work. With such an expanded contract liability, the surety could write one large bond to cover the production and managerial functions. Essentially, such a bond, in terms of the size and scope of coverage, would be indistinguishable from the large bond previously secured by the general contractor. Undoubtedly, this form of a CM contract would advance the broad industry policy concern of spreading the risk. Further, the owner would be assured of quick indemnification for negligent and nonnegligent errors from the professional liability insurer or the surety.

There is no rule of law and certainly no equitable principle which would operate to prevent the owner and the CM from entering into an agreement of this type. ${ }^{91}$ Nevertheless, firmly held economic principles and common law rules counsel against such an extreme alteration in the CM contract.

Acceptance by the CM of liability up to the entire project sum, without control over the means of production, would require the CM to have a net worth far in excess of the normal capital requirements of a professional whose only function is to provide managerial services. ${ }^{92}$ As a manager, the capital needs of the CM are insignificant. Arguably, the most important assets the CM brings to the construc-

1983, at 13-16. In this respect, the CM would be virtually indistinguishable from the ordinary general contractor in performing work, letting subcontracts, and managing the entire project.

91. It is important to recognize that there is no rule of law that would render such an agreement void $a b$ initio. This is not to say, however, that many of the policy considerations which underlie contract and tort law support the validity of such an unusual contractual arrangement.

In fact, many of these policy concerns actually cut against the desirability, if not the legality, of such a contractual relationship. See infra text accompanying notes 93-98.

92. Telephone Interview with Richard D. Conner, supra note 85. 
tion site are his experience, knowledge, and managerial expertise. ${ }^{93}$ As a result, absent unusual circumstances, the capital stock of the CM would be entirely inadequate to support a surety bond for the entire project price. To obtain such bonding capacity, the CM would be forced to overcapitalize his business, leaving much capital idle. ${ }^{94}$

Even assuming that, at the microeconomic level, the CM could survive such an inefficient overallocation of resources by substantially increasing his fee, it is apparent that macroeconomic concerns practically preclude such an option. More succinctly, the economy would become unduly shackled by the effective paralyzation of large amounts of crucial capital in order to increase artificially the bonding capacity of the CM. ${ }^{95}$ The economist would lament that such an unnatural contract obligation would unnecessarily deplete scarce resources.

Because the services delivered by the agency CM represent a relatively small percentage of the gross national product, ${ }^{96}$ this altered CM contract would not result in economic suicide. ${ }^{97}$ Neither would it, however, be inconsequential. ${ }^{98}$

93. Hart, supra note 2, at 213-17.

94. Without doubt, the foregone opportunity cost of vital capital to the CM would not be insignificant. Overcapitalization is not consistent with efficient resource allocation and profit maximization, because "[t]o maximize profits a firm [i.e., the CM] will continue to expand its investments until the internal rate of return on the marginal dollar invested is equal to the interest rate . . that prevails." $W$. Peterson, Principles of ECONOMics: Micro 352 (3d ed. 1977). With overcapitalization, capital investment is undertaken even after the marginal rate of return is exceeded by the prevailing rate of interest. Accordingly, the CM can be expected to increase his fee to compensate for his imperfect resource allocation and underutilization of capital.

95. In 1981, the amount of new construction in the United States was $\$ 237,087,000,000$. BUREAU OF The Census, U.S. Dep't of Commerce, Construction Reports-Value of New Construction Put IN PLACE 3 (Apr. 1982). Assuming that CMs were liable for all new construction work and that sureties required $\$ .10$ of net worth to support $\$ 1.00$ of bonding, an immediate capital generation of $\$ 28,000,000,000$ would be required, which is approximately $10 \%$ of all fixed business capital generated per year. See ECONOMIC REPORT OF THE PRESIDENT 124 (1979) (business and fixed investment since 1946 has ranged between $8 \%$ and $11 \%$ of real GNP). In an economy with a GNP of over $\$ 3,000,000,000,000$ (in inflated dollars), a capital generation of $\$ 28,000,000,000$ would represent nearly $1 \%$ of GNP. (In 1982 the U.S. GNP was $\$ 3,057,500,000,000$, although in constant 1972 dollars the GNP was only $\$ 1,500,000,000,000$.). Durham Morn. Herald, Jan. 23, 1983, at 9D, col. 5. For historical and estimated future GNP values see BUREAU OF THE CENSUS, U.S. DeP'T Of CommerCe, STATISTICAL ABstraCT OF THE United States 441 (1980); Pechman \& Hartman, The 1980 Budget and the Budget Outlook, in SETTING National Priorities 23, 46 (J. Pechman ed. 1979). Even though many of us have unfortunately grown accustomed to hearing large figures given by the federal government regarding many statistics of considerable concern, a number exceeding $\$ 28,000,000,000$ is manifestly significant.

96. Assuming a 3\% CM fee and that all construction work was performed under an agency CM arrangement, the agency CM would represent only $.0025 \%$ of the U.S. GNP.

97. Many economists contend that the United States suffers from a capital crisis. Moreover, many also predict that the crisis will only grow worse unless the rate of capital investment increases drastically. In describing the depth and urgency of the capital crisis one economist has explained:

Assuming that the American people desire continued economic growth, American firms must invest an enormous amount in plant, equipment, and other forms of capital in the next decade. For example, according to Roger Brinner and Allen Sinai of Data Resources, Inc., about $\$ 1.9$ trillion will have to be invested in machinery between 1975 and 1985 , compared with about $\$ 670$ billion invested in this way between 1965 and 1975. This accelerated rate of investment is due partly to the fact that our investment rate was not very high during the past decade, partly due to the increased capital requirements to satisfy antipollution and safety regulations that recently have been enacted, and partly to a variety of other factors.

If these estimates are at all reliable, the required investment is enormous by any standards. And many people, particularly in industry and on Wall Street, are worried that we won't be able to augment our capital stock at the required rate. One reason for this concern is inflation. According to 
More important, at the industry level, increasing the bonding capacity of the CM would cause a commensurate increase in his professional fee. Due to the interdependency of entities in construction, the increase in construction management costs would quickly have a harmful ripple effect throughout the industry. Such avoidable cost increases could be almost fatal in an industry operating at or near the margin, such as construction, which has been plagued by inflation, high interest rates, and insufficient demand. ${ }^{99}$

Additionally, an examination of comparable professions displays by analogy the economic impracticality of CM liability for performance. For example, doctors, lawyers, and architects receive professional fees for their services, yet they incur liability only when their services are rendered negligently. ${ }^{100}$ Were an attorney required to guarantee the outcome of litigation, the architect to assure the aesthetic acceptability of his design, and the doctor to warrant the success of an operation, an overabundance of capital would be needed by these professionals to protect themselves from inflated liability. The client of the attorney, the ownerrecipient of the design, and the patient of the doctor would soon find the fees for the services they enjoyed prohibitively expensive. The very real constraints of our economy in general, and of the construction industry in particular, dictate that such a solution is economically unsound.

Leaving aside the economic considerations, deeply-embedded principles of contract and tort law raise serious questions whether increased CM liability is consistent with the purposes and policies underlying well settled rules of our jurisprudence. Tort law imposes a duty of due care on an individual only when he

some economists, many companies will have trouble increasing their capital stock at the desired rate because their allowances for depreciation will be too small to permit them to replace worn-out equipment . . . . Moreover, they will have a difficult time borrowing money for this purpose, because they already have amassed a very large amount of debt. According to some estimates, American firms in 1975 had about $\$ 2$ of owner-provided capital per $\$ 1$ of debt, whereas in 1965 they had about $\$ 4$ of owner-provided capital per $\$ 1$ of debt.

E. Mansfield, Principles of Macroeconomics 425 (2d. ed. 1977). It is clear, therefore, that the U.S. economy can ill afford needless overcapitalization by construction management firms.

98. Although the aggregate of all agency CM fees likely represents only about $.0025 \%$ of the total U.S. GNP, a needless economic waste of such an amount due to overcapitalization would have a major ripple effect on the economy. Many economists probably agree that an increase in total output of .0025\% of GNP is significant, even if not a cause for immediate celebration. Productivity is the key to economic success. $A$ fortion any appreciable decrease in construction productivity regardless of the cause (especially if it is preventable), will have a substantial impact on the health of the economy in general and the construction industry in particular.

99. The inflation rate in the construction sector has generally exceeded the price escalation rate for the economy as a whole. U.S. DeP'T OF COMmerce, 1979 Industrial OUTLOOK 1 (1979). The lack of demand for new construction is reflected in the telling statistic that in 1979 the value of work put-in-place based on constant dollars was $6 \%$ below the level of 1978 and $15 \%$ lower than the amount in 1973. Id.; see also U.S. DeP'T OF COMMERCE, 1980 U.S. INdUSTRIAL OUTLOOK 1-7 (1980).

100. An architect is under the duty to use the skill and diligence that is ordinarily exercised by architects in their profession. First Nat'l Bank of Akron v. Cann, 503 F. Supp. 419, 439 (N.D. Ohio, 1980): Miller v. DeWitt, 37 Ill. 2d 273, 226 N.E.2d 630 (1967); Shoffner Indus., Inc. v. W.B. Lloyd Constr. Co., 42 N.C. App. 259, 257 S.E.2d 50 (1979); Davidson \& Jones, Inc. v. County of New Hanover, 41 N.C. App. 661, 255 S.E.2d 580 (1979); see also, Aetna Ins. Co. v. Hellmuth, Obata \& Kassabaum, Inc., 392 F.2d 47? (8th Cir. 1968); City of Eveleth v. Ruble, 302 Minn. 249, 225 N.W.2d 521 (Minn. 1974); Huber, Hunt \& Nichols, Inc. v. Moore, 67 Cal. App. 3d 278, 136 Cal. Rptr. 603 (1977); Normoyle-Berg Assocs. v. Village of Deer Creek, 39 Ill. App. 3d 744, 350 N.E.2d 559 (1976) (duty of reasonable care and diligence required of construction engineers). J. SWEET, supra note 5 , at 739 . 
has the ability or control to conform his conduct to meet that standard of care. ${ }^{101}$ Absent special circumstances such as an agency or master-servant relationship, an individual is not liable for the torts of another because it is presumed that he lacks the requisite control to require that person to meet the appropriate standard of care. ${ }^{102}$ The principal is not liable for the negligence of its independent contractors because there is an absence of control by the principal over the independent contractor. ${ }^{103}$ By analogy, tort law should not hold the CM accountable for performance where he has no actual control over performance. (Multiple prime contractors are independent contractors, so the doctrine of respondeat superior does not apply. ${ }^{104}$ )

In contract law, the doctrine of impossibility of performance excuses a contractual duty where "an unforeseen event which makes impossible the performance of a contractual duty occurs subsequent to the formation of the contract . . . ."105 Admittedly, making the CM contractually liable for performance without giving him control over the actual construction work is not itself an unforeseen event occurring subsequent to the formation of the contract. Under the altered CM contract, the impossibility of performance is inherent in the terms of the agreement and arises from the formation of the contract rather than its execution. Quite clearly, then, the incongruity of having a CM responsible for performance, but without the control to achieve it, fits only imperfectly under the principle of impossibility of performance. Nevertheless, equity demands that an individual should not be required to perform something that is impossible to perform,

101. Until the Sixteenth century, English common law considered that a master should not be liable for the tortious conduct of his servant unless he commanded the particular act. 1 BATY, VICARIOUS LIABILITY (1916); Wigmore, Responsibility for Tortious Acts: Its History, 7 HARV. L. REV. 315, 383 (1894); see also 3 W. HoldswOrTh, A History OF ENGlish LaW 382-87 (3d ed. 1927); 8 id. at 472-82; Prosser, LAW OF TORTS $\S 69$ (1971). This doctrine was gradually eroded so that the fiction of a command was implied from the employment itself. Brucker v. Fromont, 6 Term Rep. 659, 101 Eng. Rep. 758 (K.B. 1796); Hern v. Nichols, 1 Salk 289, 91 Eng. Rep. 256 (K.B. 1708). See generally | W. Blackstone, Commentaries 429. Nevertheless, without the necessary element of control, whether actual or implied, no liability arises for the torts committed by another. See PROSSER, LAW OF TORTS $\S 69$ (1971).

102. See Prosser, supra note 101, § 69.

103. The courts have held:

In order [to impose liability], the employer must have retained at least some degree of control over the manner in which the work is done. It is not enough that he has merely a general right to order the work stopped or resumed, to inspect its progress of [sic] to receive reports, to make suggestions or recommendations which need not necessarily be followed, or to prescribe alterations and deviations. Such a general right is usually reserved to employers, but it does not mean that the contractor is controlled as to his methods of work, or as to operative detail. There must be such retention of a right of supervision that the contractor is not entirely free to do the work his own way.

Brock v. Alaska Int'l Indus., Inc., 645 P.2d 188, 190 n.9 (Alaska 1982) (emphasis added); Moloso v. State 644 P.2d 205, 211 n.6 (Alaska 1982). Liability for the negligence of others is, therefore, premised on the existence of control over those other individuals sufficient to ensure that their conduct rises to the appropriate standard of care. See PrOSSER, supra note 101, §69.

104. Everette v. Alyeska Pipeline Serv. Co., 614 P.2d 1341, 1348 (Alaska 1980). There the court held, inter alia, that an insured worker could not recover from the pipeline project's CM who, at the time of the accident, did not retain any power to revise job specifications or to control safety procedures. The lack of control, therefore, led the court to deny a claim for liability against the CM. See also Hammond v. Bechtel Inc., 606 P.2d 1269 (Alaska 1980) (general contractor who retains control over work perfomed by the independent contractor may be liable for physical harm caused by the independent contractor).

105. J. Calamari \& J. Perillo, The law of Contracts $§ 13-1$ (2d ed. 1977). 
notwithstanding any contractual obligation to the contrary. ${ }^{106}$ One cannot be liable under contract to make objects defy the law of gravity because, despite man's ingenuity, such a task is impossible ${ }^{107}$ Likewise, where the CM has control only over management and not performance, the law should look with suspicion upon the enforcement of a contractual duty guaranteeing performance. ${ }^{108}$

A final noteworthy consideration weighing against such a fundamental change in the liability of the CM is the predictable reluctance of the CM himself to accept added contractual responsibility. The CM cannot be expected anxiously to approve of an increase in his liability without a corresponding increase in his degree of control and the amount of his fee. Moreover, the role of the CM under the new contract will likely be even more ambiguous than under the traditional agency CM arrangement. In the long run, such ambiguity might lead to a trend towards greater use of general contractors at the expense of the CM, providing even more reason for opposition by the CM.

Finally, it should be emphasized that "the verb 'manage' means to direct and control," and consequently there is a natural inconsistency in placing the burden of financial liability on the CM without granting him the requisite control over the project. ${ }^{109}$ From the foregoing analysis, it is clear that the microeconomic and macroeconomic implications, legal considerations, and practical realities in the construction industry lead inexorably to the conclusion that a revision of the traditional CM contract is an unworkable and undesirable alternative. ${ }^{110}$

106. Cf. Hammaker v. Schleigh, 157 Md. 652, 147 A.790, 794, 65 A.L.R. 1285 (1929).

107. "[A] promise imposes no duty if performance of the promise is impossible because of facts existing when the promise is made of which the promisor neither knows nor has reason to know." Faria $v$. Southwick, 81 Idaho 68, 337 P.2d 374, 376 (1959). For annotation see 17 Am Jur. 2d Contracts $\$ 144$ (1964). Concededly, a contract executed to defy the law of gravity is quite obviously an impossibility that the promisor has reason to know is impossible. Thus, under the above recital of the needed elements for discharge by impossibility of performance, the contract to defy the law of gravity would still be enforceable. This result may obtain as a matter of law; but under equity, it is likely that a court would not enforce such a contract. First Nat'l Bank v. McConnell, 103 Minn. 340, 341, 114 N.W. 1129, 1130 (1908) (the law never requires the doing of an impossible thing); see also BLACK's LaW Dictionary 680 (5th ed. 1979) (giving as an example of a physically impossible act stopping the rotation of the earth). Authority for this conclusion can also be traced back to the ancient legal maxim, "Lex neminem cogit ad impossibile" (the law requires no one to do the impossible), sometimes stated as "Ad impossibilie nemo obligatur" (beyond what he can do no one is obligated). These fundamental legal principles owe their origins to the great body of Roman law, which later became part of our Anglo-American jurisprudence. See B. STEVENSON, THE Macmillan Book of Proverbs, Maxims, and Famous Phrases 1226-27 (1948); see also H. Meneken, a New Dictionary of Quotations On Historical Principles From ancient and Modern SOURCES 580 (1966). On a more humorous note, to paraphrase the often quoted words of Charles Dickens, if the law says that a contract to defy the law of gravity is enforceable, then the law is an ass-an idiot. C. Dickens, Oliver Twist 394 (1940).

108. Cf. 17A C.J.S. Contracts $\$ 462$ (1982). "Where parties make an agreement and are ignorant at the lime that performance of the coniract is impossible, there is no contract, if it appears, on the construction of the agreement, that it was intended to be conditional on the supposed possibility of performance . . ." Id. (emphasis added).

109. Hart, supra note 2, at 223.

110. One solution to the problem of bonding the CM, which also achieves the overriding goal of spreading the risk of error among the construction industry players, is project insurance. Although this form of individualized project-by-project insurance is still in the nascent stage in terms of acceptance and use, it may well have a salutary effect on risk spreading. Under such an insurance scheme, the insured owner is protected against both negligent and nonnegligent errors that cause the product (building) to fall 


\section{Bonding the Elusive Management Function: The Need for Risk Analysis by the Owner}

The inescapable problem of bonding the management service is simply that management in any production oriented business represents a relatively small percentage of the overall cost of the enterprise. ${ }^{11}$ Managerial errors, however, have a frightfully disproportionate impact on the success of any business; this is especially true in the unique context of the construction industry, where success depends on the completion of a building on time, within budget, and in accordance with the specifications of the contract. To argue otherwise would fly in the face of the functional needs of the construction industry and the practical economic concerns of the firm at the microlevel. Management is unmistakably important in construction, yet management, when reduced to its simplest function, is merely a means to an end. This end is the building of a structure contained in the design and specifications of the architect. It is thus unsurprising that the primary functional goal in the construction industry is production, with management utilized as a means to this end. ${ }^{112}$

Thus, the bonding dilemma necessarily surfaces when the management function is separated from the production function, or more precisely, when the CM has taken over managerial control from the general contractor. The CM can be bonded separately, but the sum of the parts does not, perforce, equal the whole ${ }^{113}$ because efficiency demands the exercise of management in conjunction with production. ${ }^{114}$ Otherwise, the inimical result is inefficiency in the production pro-

below certain predetermined standards of quality. With project insurance, coverage extends beyond mere negligence, the present scope of professional liability insurance.

It should be cautioned, however, that project insurance only insures the work that is completed. Thus, the provident owner should not forego the wide protection of the performance bond because, if the general contractor defaults prior to substantial completion, the owner will be insured only for the finished work, leaving himself with an unfinished building, an insolvent general contractor, and insufficient funds to complete. As noted previously, with the performance bond the owner has performance guaranteed by the surety whose liability is co-extensive with that of the general contractor. Bonding provides the owner with a shield of security against damages incurred on the project that is not duplicated by project insurance.

It would be premature to make any strong conclusions regarding the ultimate effect of project insurance on bonding and professional liability insurance in the construction industry. To be sure, there is an uninsured gap with project insurance based on quality inasmuch as default may occur before completion. This is not to suggest, however, that an extra layer of protection may not be a desirable alteration on a given project. Nor does this imply that project insurance may not alleviate the finger pointing that invariably occurs immediately following the discovery of a negligent act or omission at the construction site.

My chief concern is that the owner must realize exactly what he is buying when he opts for project insurance. The coverages of a performance bond and project insurance are not congruent. For pedagogical purposes and pecuniary self-interest, the lesson to be learned by the owner is that he must take cognizance of this incongruence and calculate it into his cost/benefit analysis when buying protection.

111. Management of a production or manufacturing firm is simply a means to an end, the production of a good. The good is produced so that it can be sold for a profit. No profit would be possible if the needed management involved-the means to the end-exceeded the sales price of the good. Indeed, the cost of management must not only be less than the selling price-it must be greatly less because there are many other necessary and significant costs of production, such as material, labor, overhead, and capital costs. Thus, if a profit is to be made, management must represent a small percentage of the total cost of production.

112. See H. Hauf, supra note 47 , at 4 .

113. See app. A.

114. The . . basic difficulty is that the efficiencies that "large" firms [general contractors] realize are difficult to conceptualize and measure. These efficiencies derive not from economies of scale in the use 
cess. ${ }^{115}$ This inefficiency accounts for the inequality between the "big bond" for the general contractor and the sum of the CM bond and the prime contractors' bonds. Bonding the general contractor also more efficiently spreads the risk of managerial error, because prior to execution of the contract the amount of managerial risk of error involved in a project cannot be fully ascertained. Without clairvoyance, the surety cannot accurately bond the risk of managerial error, unless production and management remain coupled, as under the traditional general contractor arrangement. Thus, proper and complete bonding necessarily requires that management remain attached to the production function. Any premature separation of management from production invariably and unavoidably augments the risk that the bond coverage will not be sufficient for egregious managerial errors.

As noted previously, in terms of the absolute amount of protection for the owner, the traditional arrangement is unequivocally superior because of the layering effect. ${ }^{116}$ With the CM, there is no aggregate bond covering the entire project; ${ }^{117}$ there is only one layer, rather than two layers, of bond protection afforded the owner.

What does this analysis imply about the desirability of employing a CM on a project? It cannot be gainsaid that efficient and effective management is extremely important and that an able CM can provide, as his name implies, a level of managerial expertise that cannot be duplicated. ${ }^{118}$ The CM was born of a need that survives undiminished today. ${ }^{119}$ Nonetheless, contrary to conventional wisdom in the industry, the agency CM arrangement contains many hidden perils.

of facilities and equipment but from the elusive improvements that can be achieved when resources are placed under the control of a single management. These improvements are attributable, ultimately, to a better flow of information about the possible uses to which the resources can be put. The evaluation of the improvements depends on unresolved issues concerning the consequences of subjecting resources to different forms of internal control within a single firm, as compared to having their uses determined by competition among independent owners of them .... Large firms [general contractors] do achieve significant efficiencies, even if we cannot quantify these efficiences with any real confidence.

Schwartz, Should American Industry Be Deconcentrated?, in THE ATTACK ON CORPORATE AMERICA 284 (M. Johnson ed. 1978) (emphasis added). Even though the foregoing conclusion that maximum efficiency requires unitary management was reached following an analysis of the merits of increased overall firm size, the same conclusion logically applies with equal cogency in the particular and analogous context of construction management.

115. Id. The managerial inefficiency caused by the separation of management from production has not been empirically demonstrated. This inefficiency is a direct result of the apparently insurmountable difficulty encountered in controlling the many variables that affect managerial efficiency. Controlling such variables is necessary to measure statistically with reliability the gain or loss resulting from deconcentrating the management function. The unsurprising lack of data, however, does not render the reasoned conclusion ipse dixit, nor does it make the logic any less compelling.

116. See supra text accompanying notes 76 \& 77; see also Hart, supra note 2, at 223.

117. Hart, supro note 2, at 223.

118. "The ability to lay out and rapidly display one's plans for the future and the advent of readily available monitoring systems for measuring progress in time and dollars have put the contract manager in the forefront." (emphasis supplied). H.M. HOHNS, supra note 26, at 30.

119. Recent empirical studies reveal the pervasive and distressing inefficiency inextricable to construction. For example, only $32 \%$ of the total time spent at a construction site involves actual direct work. The remainder of the time is divided as follows: (1) 7\% for equipment transportation delays, (2) 13\% for traveling on the job site, (3) $29 \%$ consumed by waiting delays, (4) $8 \%$ for late starts and early quits, (5) $6 \%$ receiving instructions, and (6) $5 \%$ for personnel breaks. Even if the time spent on personnel breaks and receiving instructions is added to direct work, approximately $57 \%$ of the entire time at the construction site 
The owner clearly loses bonding protection under such a regime. In other words, there is a trade off between less protection weighed against superior management, possible cost savings, and possible decreased time to completion.

The prudent owner should undertake a risk analysis on a project-by-project basis to determine whether to retain the traditional general contractor arrangement or choose the agency CM. When there is an extra premium placed on speed and managerial expertise, or simply when the project entails little risk, ${ }^{120}$ the owner is likely to place his confidence in the CM. When, however, the project is very large and the perceived risk of encountering uncertain problems is inordinately high, ${ }^{121}$ the sage owner may reasonably forego the expertise of the CM and rely on the greater protection afforded by the traditional regime. ${ }^{122}$ In sum, the surety driven by economic self-interest clearly prefers the traditional arrangement because the aggregate value of the bonds is greater as a result of the layering effect. ${ }^{123}$ From the industry perspective, the traditional arrangement is again preferable because the risk of nonnegligent error is spread more evenly and thinly throughout the industry. ${ }^{124}$

is consumed by nonproductive activities. The most ominous and revealing statistic is, however, that fully $29 \%$ (nearly one-third of all the time at the site) is exhausted by waiting.

Although waiting may provide laborers with an enviable amount of compensated leisure, it represents pure inefficiency. At the macrolevel, with such an enormous amount of inefficiency, it is neither the contractor nor the owner (assuming the contract price accurately reflects the predicted productive loss due to waiting) who ultimately bears the cost of construction inefficiency. The welfare loss caused by construction inefficiency is silently absorbed by society as a whole. In the final calculation, the real loser is society insofar as the contractor passes on the cost of waiting in the contract price to the owner, who then transfers the cost to the tenant as part of the rent, or to the consumer of goods or services by increasing the cost of goods sold to reflect the added cost of waiting. Address by Professor James A. Adrian at the Seminar for the Construction Management Association in Columbia, S.C. (July 23, 1982).

The remaining, yet difficult question is simply why is the construction industry plagued by such inefficiency? Although I am neither an industrial engineer nor a microeconomist, my observational hypothesis is that the very nature of the construction industry with its many contractual relationships and parties all working on the same structure leads ineluctably to that great nemesis-inefficiency. It has frequently been my experience in construction litigation, that the number of parties involved in a single construction dispute may easily exceed 50 . Indeed, on some extremely large projects the number may easily escalate even above 50. As the number of parties involved on a project grows, the concomitant transactions cost also increases. With so many parties, each under a different management and each marching to the beat of a different drummer, it is unquestioned that, even more so than most industries, the construction industry is marked by inherently poor productivity. Ironically enough, poor productivity resulting from mismanagement is the very mischief that the CM was created to alleviate, or more optimistically, eliminate.

120. An obvious example of a project encompassing little risk would be a warehouse with much of the outer structure prefabricated.

121. A high risk project might include one that is architecturally unique, built on an unsure foundation, such as accumulated fill, and that carries a high contract price.

122. The problem is, however, that the risk analysis may not lead to a clear decision. It is frequently the case that, when the benefits of the CM are most helpful and desirable, the inherent risk of the project is greatest. A large complex office galleria may demand the managerial expertise of a CM, yet such a project is a high risk endeavor, requiring the added bond protection.

123. See app. A.

124. The absolute amount of risk involved in any project is identical regardless of the nature of the specific regime adopted; however, the burden of risk is not spread by the surety as well under a CM arrangement as compared to the traditional regime. 


\section{VI \\ Design-Build/Fast Track Construction}

\section{A. Description of Design-Build/Fast Track Construction}

Another departure from the traditional construction contract alignment and methodological approach which in recent years has grown in popularity is designbuild/fast track construction. Although the techniques of construction involved in design-build/fast track may be used independently of each other, they are more often used in conjunction and thus will be treated as a single unit for the purposes of this article.

Design-build/fast track differs from the traditional construction method in two very significant ways. ${ }^{125}$ First, in design-build, one party contracts with the owner to perform both the design and construction functions on a project. ${ }^{126}$ Thus, the project has no independent design professional to fill in the traditional duties of the architect. ${ }^{127}$ The party contracting with the owner agrees to produce the finished product from beginning to end. ${ }^{128}$

The second fundamental departure is that, in fast track, the design period overlaps with the construction phase of a given project. In the traditional arrangement, an architect prepares detailed design documents and specifications upon which the general contractor bases its bid for negotiated price, and thus construction does not begin until the design and bidding processes are complete. In fast track, on the other hand, construction begins before the design is finished. ${ }^{129}$ In fact, initial construction may commence based only upon rough schematic drawings. ${ }^{130}$

Three types of contract provisions for payment are generally utilized in design-

125. See generally Note, Design-Build Coniracts in Virginia, 14 U. RICH. L. REV. 791, $798-99$ (1980).

126. Id. at 798. In respect to design-build construction, one court has remarked:

Its purpose is to allow construction to start while the final drawing and details are being prepared so that work on the detailed engineering plans can proceed during the time that preliminary construction is underway.

In theory, this type of arrangement should permit the work to move more rapidly and result in completed construction at an earlier date. It is obvious, however, that since many details have not been agreed upon by the parties before work begins, that opportunities for error, delay and expensive changes are increased over those not infrequent instances which might be expected in the normal construction contracts.

Armour \& Co. v. Scott, 360 F. Supp. 319, 320 (W.D. Pa. 1972), affd, 480 F.2d 611 (3d Cir. 1973). The Court here, however, incorrectly articulates the proper definition for design-build construction. The accepted definition for design-build construction is a contractual arrangement whereby the general contractor provides both the design and construction functions for a particular project. In Armour, the court confuses "design-build" with "fast track" or simply the beginning of construction before the plans and specifications are complete. Such judicial confusion is a common occurence appearing throughout many judicial and arbitral opinions on the subject.

127. See supra notes $26-36$ and accompanying text.

128. Note, supra note 125 , at 798.

129. Meyer, A Glossary of Construction Terms, 14 Forum, 924, 929 (1979); see also Hapke, supra note 4.

130. Fast track has been described as a

method of construction by which actual construction is commenced prior to the completion of all design, planning, bidding and subcontracting stages in order to alleviate the effects of inflation

Under the "fast track" method of construction, plantiffs were required to perform those services ordinarily performed by the general contractor in addition to the normal architectural services.

Meathe v. State Univ. Constr. Fund, 65 A.D. 2d 49, 50, 410 N.Y.S. 2d 702, 703 (1978). 
build/fast track construction. The first is a provision for a lump-sum price for the entire project, even though based on incomplete plans and specifications. The second involves a cost-plus arrangement for the first portion of the project (or costplus for construction and fixed-fee for design) with a final lump-sum price established when the design plans and specifications are complete. The final type of payment provision is a straight cost-plus-a-fixed-fee arrangement. ${ }^{131}$

Obviously, these disparate methods of computing the cost of the work reflect a conscious allocation of the risk involved in setting a price before the precise scope of the work is known. In the first alternative, the risk of estimating the scope of the work is borne entirely by the contractor; ${ }^{132}$ in the third, it is borne entirely by the owner. The second variation, which itself has permutations, ${ }^{133}$ is an attempt to solve the problem of risk allocation by deferring a final price until, as in the traditional arrangement, the plans and specifications are finalized. In fact, however, the second mode, like the third, forces the owner to bear the entire risk. At the completion of the design phase, he has no firm price to completion, and he is faced with the Hobson's choice of accepting whatever price may be quoted by his original design-build/fast track contractor or seeking a new contractor and thereby sacrificing, to a second mobilization and learning curve, all his hard bargained for advantages of reduced time to completion. In addition, in this second contractor scenario, an owner may be sure that the price he is quoted will include a substantial premium for the risk taken by the new contractor in assuming the completion of work begun by another.

\section{B. Problems Faced by the Surety in the Design-Build/Fast Track Arrangement}

The design-build/fast track method of construction presents at least three sig-

131. Businessman's Guide TO CONSTRUCTION, supta note 85, at 227.

132. There appears to be no reported authority assessing the risk allocation which results from shifting the design function from the independent design professional employed by the owner to the design-build contractor, especially one in a fast track mode. The logical implications are, however, readily apparent.

In the traditional mode, the owner is universally held to warrant the sufficiency of the plans and specifications to the contractor because they are prepared by his agent, the design professional. United States v. Spearin, 248 U.S. 132, 137 (1918); see also Annot., 6 A.L.R.3d 1394, 1397 (1966). Conversely, the contractor's interpretation of ambiguous or incomplete plans and specifications, if reasonable, is controlling, although it is not the only possible interpretation or even the best interpretation. This rule follows from the general canon of interpretation that an ambiguous contract provision will be construed against the drafting party (owner) and in favor of the other party (contractor). See, e.g., Cheveron Oil Co. v. E.D. Walton Constr. Co., 517 F.2d 1119 (5th Cir. 1975).

When the design function is shifted to the contractor, the warranty must flow from him to the owner, rather than the opposite, and now it is the owner's interpretation, if reasonable, which will determine the scope of a Guaranteed Maximum Price (GMP) contract. Similarly, when the fast track element is added, a contractor will be held to have assumed the responsiblity to provide in a complete form all systems or items of work shown or necessarily implied from the schematics, outline specifications, or other contract scope documents in existence at the time of contract formation. Such systems or items of work must be provided in such a fashion as to produce the result delineated by the owner in the contract documents, in essence, a performance specification. Naturally, the limit of this responsibility will be a properly functioning end product but without "gold plate."

133. For example, the contract may provide for a budget estimate at the conclusion of the design phase. The contractor will then submit a rebid; the owner is free to accept it or reject it and seek a successor contractor, now in the traditional relationship, to complete the work. 
nificant problems to the surety who is called upon to write a performance bond: (1) it is often difficult for the surety to determine the scope of work involved in the contract; (2) the cost of the separate functions of design and construction are often not allocated under the single design-build/fast track contract; (3) the absence of an independent architect representing the owner to certify completed work opens the door to nonconforming work and improper payment of contract funds. The following analysis details each of these problems and offers suggestions for their mitigation or solution.

That a contract must be bonded by a surety based on incomplete documents makes impossible an accurate appraisal of exactly what is within the scope of the work. No matter which form of payment is selected, the surety faces the significant possibility of writing a bond of improper size. If the surety is too high in his estimate of a project's cost, the cost of the project is needlessly increased by the fees for the excess bond. If the penal sum falls short of the true cost of the work involved, the owner has not received a full guarantee, for which he is willing to pay, and the surety has missed an opportunity for bond fees on this initially needed, but omitted, performance bond.

More important to the surety, when the scope is indeterminate, he has guaranteed the completion of a project which may vastly exceed the contract (and bond) sum, thereby assuming for himself the risks inherent in design-build/fast track construction, subject only to his indemnity from the contractor/principal. In other words, the necessity of bonding a design-build/fast track job will fundamentally lessen the net worth multiple applied by a surety to establish bonding capacity. From a microeconomic point of view, a given contractor must then increase his profit margin to offset his diminished volume; from a macroeconomic view, the entire construction industry suffers a reduction in its capacity (or must inefficiently utilize additional capital) to take into account reduced aggregate bondability.

One possible solution to this problem of inaccurate bonding caused by incomplete project information is the use of incremental bonding. Under such a scheme, the surety writes performance bonds for the various segments of a project at the same time the design drawings and specifications, as well as cost estimates, are completed. In this manner, the surety may bond using full information, and the possibility of writing too large or too small a bond is measurably diminished.

This incremental bonding method, however, also involves some potential problems. First, the system requires continued vigilance by the owner and the surety (if he wants his fee) to ensure that the contractor is continually updating his bond. Second, while most sureties willingly write bonds if a contractor has sufficient bonding capacity, it is reasonably foreseeable that a project could reach a point in either the design or construction phases where a surety would refuse to bond it further. This refusal would leave the owner with a partially bonded project and the difficult prospect of finding a surety willing to guarantee completion of a project which has already encountered major problems. Finally, despite the conceptual ease of dividing a project into discrete parts which may then be designed, specified, priced, and bonded separately, this may not always be possible 
in the real world of construction. The interdependence of the various systems and trades in the construction industry makes an accurate projection of a final price for a particular drawing virtually impossible. As a result, incremental bonding is rare.

A more effective solution to this problem, and one which may also remedy the underlying difficulty of allocating the risk of incomplete design between the owner and the contractor, is the guaranteed maximum price based upon unit assumptions (GMPBUA). In this format, a bidding or negotiating contractor is responsible for furnishing the owner with a far more detailed schedule of values than under the contract documents applicable to traditional construction. ${ }^{134}$ In practice, the more detailed breakdown into items or segments of the work, the better. As a practical matter, it would be useful for this schedule to correspond to the designer's anticipation of the list of final project drawings.

In the GMPBUA format, each line item is complemented and supported by labor, materials units, and pricing. ${ }^{135}$ In addition to forming the basis for adjustment of the guaranteed maximum price as a result of design completion, such a breakdown enables the owner and competing contractors to identify systems of work upon which the contractors have disparate views of either units or costs. ${ }^{136}$ When the design is complete, a final take-off of materials can be made and the price adjusted in proportion to this take-off. The component of the price which reflects labor units is adjusted only in respect to increased or decreased materials; this method protects the owner against contractor inefficiency, yet allows the contractor to realize its traditional profit upon efficient production. The remaining risk to the owner-design and installation of excessive materials-should be recognized as a hazard when the owner considers this project delivery system.

The second major problem facing the surety in the design-build/fast track arrangement is to determine what part of the contract sum should be allocated to bondable construction work and what part allocated to the generally unbonded functions of the design professional. Design-build/fast track contracts often do not allocate costs between the construction and design functions; thus, the possibility of an inaccurate bond amount is again present. The obvious solution to this problem is for the owner or surety to require an allocation of the design-build/fast track contract between cost for (1) design and contract administration and (2) actual construction.

The final problem facing the surety in design-build/fast track construction is somewhat more significant and perhaps even more difficult to solve than either of those discussed above. The lack of an independent architect tremendously increases the potential for improper payment of the contract funds by the owner. In the traditional contract arrangement, the architect has responsibility for issuing Certificates for Payment; these are the architect's representation, based on an observation of the quality and quantity of work performed, that the contractor is

134. AIA General Conditions, supra note 42 , art. 9.2.1.

135. Overhead and profit are covered by a fixed fee, part of the GMP, expressed as a percent of the total base cost.

136. Because an apples-to-apples comparison is a further subject of the exercise, the owner should prepare and furnish the detailed schedule of the work. 
entitled to payment for the amount certified. ${ }^{137}$ Thus, the owner and surety have an independent observer to protect them from improper payment. In contrast, the typical design-build/fast track arrangement does not provide for an independent party to certify payment. The owner and surety must rely upon "a representation by the Contractor to the Owner that the Work has progressed to the point indicated and that the quality of the Work is in accordance with the [Contract Documents]." 138

The potential for abuse in this situation is tremendous. Plainly, the surety suffers in the case of a default when a contractor has been overpaid for the amount of work he has completed. If the surety assumes performance, he is responsible for the total cost of completion less the unpaid contract balance, even if the net cost exceeds the penal limit of the bond. ${ }^{139}$ Thus, as the contract balance remaining to be paid by the owner becomes smaller, the surety's liability becomes greater. Upon default, improper early payment also increases the surety's liability even if the surety opts to allow the owner to complete the job. While the surety in such a situation has only to pay the owner's loss not exceeding the penal amount of the bond, ${ }^{140}$ the owner's overpayment to the defaulting contractor will correspondingly increase both the owner's cost to complete and the amount of the surety's liability up to the penal amount of the bond.

A surety caught in the situation when a defaulting design-build/fast track contractor has been overpaid should be aware that he has a cause of action against the contractor who improperly certified payments. ${ }^{141}$ While the surety may also seek indemnity from the defaulting contractor for any loss suffered, it will be much easier for the surety to recover for his loss based on an action for negligent payment because such an error is likely covered by the professional liability insurance carried by the contractor for his design professional functions. ${ }^{142}$ This professional liability insurance coverage is the most practical solution to the problem of negligent payment. However, both the owner and surety should examine the policy's coverage to assure themselves that improper payment is an insured risk, and they should request a special endorsement if necessary. In addition, the owner and surety may want to consider requiring that they be named additional insureds and furnished with a certificate of insurance, together with notice of any lapse.

An even better but less practical solution would be the development of a check on a certification of payment, either by the owner or the surety. Effective implementation of such an arrangement, however, requires not only knowledge and

137. AIA Owner-Architect Agreement, supra note 26, art. 1.5.8.

138. Business MAN's GUIDE TO CONSTR UCTION, supra note 85, at 229 (emphasis added) (the editors provide a sample design-build contract).

139. See, e.g., McWaters \& Bartlett v. United States, 272 F.2d 291 (10th Cir. 1959).

140. AlA Performance Bond, supra note 47. However, at least one court has held a surety liable for amounts in excess of the penal limit of the bond, where completion was undertaken by the owner. See Continental Realty Co. v. Andrew J. Crevolin Co., 380 F. Supp. 246 (S.D. W. Va. 1974).

141. See Peerless Ins. Co. v. Cerny \& Assocs., Inc., 199 F. Supp. 951, 955 (D. Minn. 1961) (architect held liable for negligent certification of payment). See generally Murphy, The Impact of the 1976 Edition of AIA Document A201 on the Liability of Architects and Engineers to the Construction Surety for Negligent Certification of Payments, 45 Ins. Couns. J. 200, 209 (1978).

142. Insurance Policy, supra note 81. 
expertise far beyond that of the typical owner, but also that the surety either maintain a staff of quantity surveyors on a permanent basis or employ an independent engineer ad hoc. While such an arrangement is well established for lenders and some experienced public owners on major projects, for sureties it is not yet the rule or even the frequent exception. Thus, short of the introduction of an independent professional with the proper knowledge and expertise, a system of owner or surety review is in all likelihood practically unworkable.

Most certainly, the design-build/fast track arrangement presents several areas of potential problems for the surety. ${ }^{143}$ Determining the scope of the work with accuracy, properly computing the bondable portions of the contract sum, and ensuring against improper payment of contract funds are three significant areas to which a surety writing a performance bond on design-build/fast track projects should give careful attention. The surety might well determine that the risk involved with bonding design-build/fast track projects warrants higher fee schedules.

Similarly, against the time value of money and facility utilization value he achieves, an owner considering this form of project delivery must weigh the inherent risk which these problems pose to him and the cost of adequate and independent professional advice which is demanded to achieve workable solutions. As in the case of the CM, it is not possible to eliminate the cost of necessary services simply by shifting them from one participant in the construction scenario to another.

\section{VII}

\section{Conclusion}

Not long ago, the introduction of the CM into the traditional construction arrangement and the development of design-build/fast track construction methods were hailed as the much needed curative therapy for an industry beleaguered by

143. The surety is not the only party in construction that may be adversely affected by the imprudent and unwarranted resort to design-build/fast track construction in projects that are grossly inappropriate for the application of these new construction methods. To the extent that design represents the most important and delicate phase in construction and the interjection of fast tracking unavoidably upsets the design process, it follows that fast track construction may frequently detrimentally affect the other parties to construction as well as that familiar character-the surety. In emphasizing the importance of the design process to the ultimate success of a project, at least one commentator has remarked that,

$[t]$ he design phase is the critical period in which to prepare a framework which will minimize future controversies and disputes. Each party has its own interests to advance and protect . . . . [The interests of the owner, architect, and contractor] are not necessarily compatible. Awareness and compromise are required in all stages of the planning and construction process to unite these competing interests, thereby minimizing construction disputes. Some problems are inevitable, but careful planning and attention to detail in design and contract drafting should minimize controversy.

Wulfsberd \& McNabb, The Law Behind Today's Constnction Contracts, in H.M. HoHns, supra note 26, at 75. In the light of the primacy of the design phase, it is axiomatic that the introduction of fast tracking only serves to exacerbate and multiply the inherent difficulties and problems that are already extant in the ordinary design of a building. This is the reason why the surety understandably waxes at tentive whenever he discovers that the owner intends to fast track a project. What is even more incomprehensible is that owners typically request fast tracking on projects that are particularly ill-suited for such an accelerated construction method. 
inflation and a disappointingly low demand for new construction. ${ }^{144}$ Contrary to initial expectations, neither construction management, as an organizational concept, nor design-build/fast track, as a means and methods concept, proved as useful at the construction site as orginally anticipated. Even more important, it is plainly evident that both of these new developments present serious problems of bonding and consequent risk spreading that do not otherwise exist. This conclusion is not to suggest, however, that on many projects construction management and design-build/fast track construction will not be desirable departures from the traditional arrangements and methods. ${ }^{145}$ The lesson to be learned is simply that, when evaluating whether to utilize a CM or to adopt design-build/fast track construction for a particular project both the owner and the surety must take cognizance of the resulting bonding problems and reduction in risk protection associated with these novel construction approaches. The owner must recognize what the surety has silently known: neither the CM nor design-build/fast track construction has a monopoly on innovative virtue, and thus the problems of bonding which each presents should not be overlooked.

144. 1980 U.S. INDUSTRIAL OUTLOOK, supra note 99, at 1-7; 1979 U.S. INDUSTRIAL OUTLOOK, supra note 99 , at 1 .

145. As noted previously, it is a question of risk analysis with the perceived benefits of construction management and design-build/fast track construction weighed against the inherent and unavoidable bonding problems which they present. 


\section{APPENDIX A}

An example of the effects on bonding in the traditional alignment vs. the agency CM alignment is as follows:

Traditional

General Contract Total .

[Assumptions: the contract price includes a markup of $5 \%(\$ 500,000)$ based on 18 month completion time, and the General Contractor will perform $\$ 1,500,000$ of work with his own forces.]

Bond on General Contract

$\$ 10,000,000$

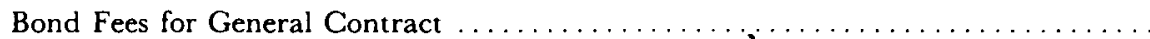

Subcontracts Total

[Assumptions: The subcontracts include two bonded subcontractors (electrical and mechanical) at $\$ 1,200,000$ each; four bonded subcontractors (steel, masonry, wall systems, etc.) at $\$ 500,000$ each; fifteen subcontractors for the remainder of the work at $\$ 240,000$ each, of which ten are bonded.]

Bonds on Subcontracts.

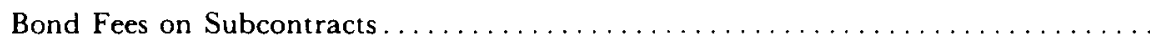

Total Bonds

$\$ 16,800,000$

$168 \%$

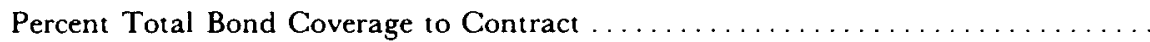

Total Bond Fees

$\$ 135,450$

\section{Agency CM}

\section{CM Unbonded}

Total Contract Price

Assumptions: The multi-prime contractors include one bonded prime contractor at $\$ 1,500,000$; two bonded prime contractors at $\$ 1,200,000$ each; four bonded prime contractors at $\$ 500,000$ each; fifteen prime contractors at $\$ 240,000$ each, of which ten are bonded. The contract price also includes a CM at $\$ 300,000(3.2 \%)$.]

Total Bonds

Total Bond Fees

$\$ 8,300,000$

$\$ 88,200$

Percent Total Bond Coverage to Contract

$85 \%$

Savings on General Contractor Markup

$\$ 200,000$

Savings on Bond Fees

$\frac{\$ 7,250}{\$ 247,250}$

Total Savings

$\$ 247,250$

2. Bond the Existing CM Contract

Total Contract Price

[Assumptions: Same as \#1 above]

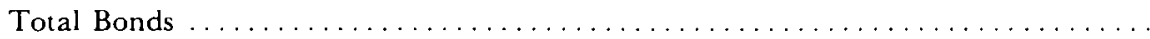

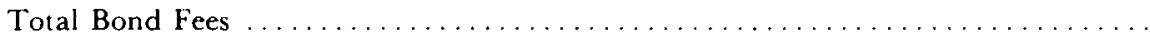

Percent Total Bond Coverage to Contract . . . . . . . . . . . . . . . . .

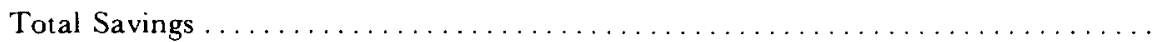

3. Bond CM for the Entire Project

Total Contract Price

$\$ 9,800,000$

$\$ 8,600,000$

$\$ 91,800$

$88 \%$

$\$ 243,650$

[Assumptions: Same as \#1 above]

Total Bonds .

$\$ 9,800,000$

Total Bond Fees $\ldots \ldots \ldots \ldots \ldots \ldots \ldots \ldots \ldots \ldots \ldots \ldots \ldots \ldots \ldots \ldots$

Percent Total Bond Coverage to Contract $\ldots \ldots \ldots \ldots \ldots \ldots \ldots \ldots \ldots \ldots$

$\$ 18,100,000$

$\$ 147,240$

$185 \%$

Total Savings 
